\title{
Land-cover change threatens tropical forests and biodiversity in the Littoral Region, Cameroon
}

\author{
Mahmoud I. Mahmoud, Mason J. Campbell, Sean Sloan \\ Mohammed Alamgir and William F. Laurance
}

\begin{abstract}
Tropical forest regions in equatorial Africa are threatened with degradation, deforestation and biodiversity loss as a result of land-cover change. We investigated historical land-cover dynamics in unprotected forested areas of the Littoral Region in south-western Cameroon during 1975-2017, to detect changes that may influence this important biodiversity and wildlife area. Processed Landsat imagery was used to map and monitor changes in land use and land cover. From 1975 to 2017 the area of high-value forest landscapes decreased by c. $420,000 \mathrm{ha}$, and increasing forest fragmentation caused a decline of c. $12 \%$ in the largest patch index. Conversely, disturbed vegetation, cleared areas and urban areas all expanded in extent, by $32 \%$ (c. 400,000 ha), $5.6 \%$ (c. $26,800 \mathrm{ha}$ ) and $6.6 \%$ (c. $78,631 \mathrm{ha}$ ), respectively. The greatest increase was in the area converted to oil palm plantations (c. 26,893 ha), followed by logging and land clearing (c. $34,838 \mathrm{ha}$ ), all of which were the major factors driving deforestation in the study area. Our findings highlight the increasing threats facing the wider Littoral Region, which includes Mount Nlonako and Ebo Forest, both of which are critical areas for regional conservation and the latter a proposed National Park and the only sizable area of intact forest in the region. Intact forest in the Littoral Region, and in particular at Ebo, merits urgent protection.
\end{abstract}

Keywords Biodiversity loss, Cameroon, deforestation, Ebo Forest, equatorial Africa, logging, oil palm, roads, wildlife

Supplementary material for this article is available at https://doi.org/10.1017/So030605318000881

\section{Introduction}

A frica's tropical forests are the most extensive after those of the Amazon (Cincotta et al., 2000; Sosef et al., 2017), covering 3.6 million $\mathrm{km}^{2}$, with the majority concentrated in the greater Congo Basin. These forests harbour c. 2,000 species of vertebrates and $>10,000$ plant species (Orme

Mahmoud I. Mahmoud (Corresponding author, (D) orcid.org/0000-0002-04320429), Mason J. Campbell, Sean Sloan, Mohammed Alamgir and William F. Laurance Center for Tropical Environmental and Sustainability Science, College of Science and Engineering, James Cook University, Cairns, Queensland 4878, Australia. E-mail mahmoud.mahmoud@jcu.edu.au

Received 4 May 2018. Revision requested 12 June 2018.

Accepted 13 June 2018. First published online 29 August 2019. et al., 2005; WWF, 2017). They also provide numerous and valuable environmental services, including carbon storage, protection of threatened ecosystems, hydrological functioning (Abernethy et al., 2016), and medicinal products (Colfer, 2012). African forests also provide significant socioeconomic resources, including plant and animal products, food, medicine, products of cultural value, and building and construction materials.

Tropical African forests are threatened by a wide array of anthropogenic activities that imperil natural ecosystems and biodiversity. For instance, the few previous studies conducted in the threatened forests of the Cross-Sanaga River region (Fa et al., 2006), the Gulf of Guinea biodiversity hotspot (Oates et al., 2004), and the greater Congo Basin (Laurance et al., 2015) identified deforestation as a major factor driving both forest loss and degradation (Hosonuma et al., 2012; Ordway et al., 2017; Aleman et al., 2018). Deforestation, along with other smallholder activities in African tropical forests, is also known to damage important wildlife habitats, leading to biodiversity loss and the destruction of forest-based livelihoods. However, the extent to which small vs large landholder activities influence landcover change and conservation in these forests remains unclear. Known drivers of forested land-cover conversion include industrial logging (Laporte et al., 2007), agricultural expansion (van Soesbergen et al., 2017), settlement expansion (Mahmoud et al., 2016) and road infrastructure expansion (Alamgir et al., 2017; Laurance et al., 2017; Mahmoud et al., 2017). These processes can also lead to forest fragmentation and degradation, resulting in depauperate forests with significantly reduced biodiversity compared to intact forests (Fahrig, 2003; Haddad et al., 2015; Laurance et al., 2018).

The rate and scale of land-cover change currently occurring in equatorial Africa is unprecedented and unsustainable (Tchuenté et al., 2011). However, there is a paucity of studies examining human-driven land-cover change and threats to conservation at fine spatial scales in unprotected yet still highly biodiverse regions of equatorial Africa. Regional studies examining land-cover change have often been at a coarse scale, and many of the findings are based on inferences (Singh et al., 2017; Thompson et al., 2017). Consequently, many of these regional studies overlook challenges associated with localized land-use and land-cover change processes such as selective logging, small-scale logging, land clearing and the establishment of smallholder oil palm plantations, particularly in areas of high biodiversity 
containing disturbance-sensitive wildlife. Understanding underlying land-use and land-cover change processes and patterns retrospectively at a detailed scale is important for conservation managers, as it can facilitate the development of sustainable socio-ecological management solutions for addressing current and imminent environmental challenges in these forests.

Southern Cameroon is experiencing rapid forest loss (Cheek et al., 1996; Ingram et al., 2017). The Littoral Region, in south-western Cameroon, has the largest area of continuous tropical forest, within the Nkam and SangaMaritime areas, bordering the Ebo and Dibamba rivers north of Cameroon's industrial capital Douala. This area includes the proposed Ebo National Park, which is among the few remaining intact forest landscapes in Africa north of the Sanga River (Potapov et al., 2017). However, Ebo Forest remains legislatively unprotected despite efforts to designate the area as a National Park. Ebo Forest provides important habitat for the Critically Endangered Preuss's red colobus Piliocolobus preussi and gorilla subspecies Gorilla gorilla diehli and Gorilla gorilla gorilla, the Endangered NigeriaCameroon chimpanzee Pan troglodytes ellioti and drill Mandrillus leucophaeus, and the Vulnerable African forest elephant Loxodonta cyclotis (Morgan et al., 2011, who also provide further details of the ecology and geography of the region). Given the unprotected status of Ebo Forest, it remains particularly vulnerable to anthropogenic pressures such as deforestation and hunting, especially considering the unprecedented scale and pace of deforestation in the surrounding areas. These threats remain unchallenged because of delays in securing legal protection, thus threatening the long-term integrity of Ebo Forest.

The Littoral Region of Cameroon also encompasses Mount Nlonako, along the north-western axis of the region. Mount Nlonako has a rich diversity of amphibians, birds and reptiles but is subject to human incursions. Both Mount Nlonako and Ebo Forest are located in relatively close proximity to Douala (Mount Nlonako c. $89 \mathrm{~km}$ to the north-west of the city, and Ebo Forest c. $56 \mathrm{~km}$ to the north-east). With its proximity to wildlife habitat, Douala supports thriving markets for forest products and wildlife, many of which supply bushmeat. The high demand for forest and wildlife products is a strong driver of the ongoing depletion of natural forest cover and biodiversity through logging and hunting in the unprotected forests of the Littoral Region and greater Cameroon (Morgan et al., 2011). It is therefore important to ascertain how human land-use actions affect unprotected high-value forests at the landscape level across the wider Littoral Region, using combined remote sensing and geographical information system (GIS)-based analysis (Wiens et al., 2009; Willis, 2015), in the interest of environmental sustainability (Cetin, 2015). There have been no previous detailed studies of anthropogenic land-use/land-cover changes and their implications for tropical forest conservation in the Littoral Region or in equatorial Africa as a whole.

The history of extensive forest loss in the Littoral Region is poorly documented, and its drivers are poorly understood. Here, we provide spatially explicit land-cover change analysis and information about forest fragmentation. We also discuss the potential influence of these human actions on the long-term sustainability of natural forest conservation. To achieve these aims, we addressed the following questions: (1) How have land surface dynamics changed in the Littoral Region from 1975 to 2017? (2) What are the drivers of land-cover change? (3) How may land-cover change imperil future conservation of critical biodiversity and wildlife habitats?

\section{Study area}

We examined a $13,845 \mathrm{~km}^{2}$ study area encompassing Ebo Forest $\left(\right.$ c. $\left.1,500 \mathrm{~km}^{2}\right)$ in the Littoral Region of Cameroon (Fig. 1). Mean annual precipitation in the area is 1,500$2,000 \mathrm{~mm}$ in the northern and interior regions, and 2,000-3,000 $\mathrm{mm}$ in the southern and coastal zones. Mean annual temperature is $25-28{ }^{\circ} \mathrm{C}$ (Molua, 2009). The landscape is relatively flat, although there are some areas of undulating terrain, and a few mountains rising to $1,200 \mathrm{~m}$ inside the boundaries of the proposed Ebo National Park (the proposed boundaries are currently under review).

Human activities in the Littoral Region, such as unsustainable levels of logging, selective logging, land clearing, farming and hunting, place the regions' biodiversity (including that in Ebo Forest) under severe threat (Morgan et al., 2011; Whytock et al., 2016). Large-scale bushmeat wholesalers travel to local villages near Ebo Forest by timber trucks, motorcycles and taxis to buy bushmeat from hunters to supply the region's rapidly increasing population (from 2.5 million in 2005 to nearly 3.5 million in 2015). In addition, the humid equatorial climate of the Littoral Region makes it a suitable location for oil palm plantations. Palm oil production is expanding rapidly, with small- to medium-sized oil palm plantations replacing lands previously used for crops such as cocoa and coffee (Feintrenie, 2012).

\section{Methods}

\section{Study overview}

We assessed land-cover change in the Littoral Region based on the available historical remote-sensing images from Landsat-4 (multispectral scanner, $60 \mathrm{~m}$ resolution) for 21 December 1975 and Landsat-8 (operational land imager, $30 \mathrm{~m}$ resolution) for 26 December 2017. Land-cover data were integrated using GIS overlays of Google Earth and 


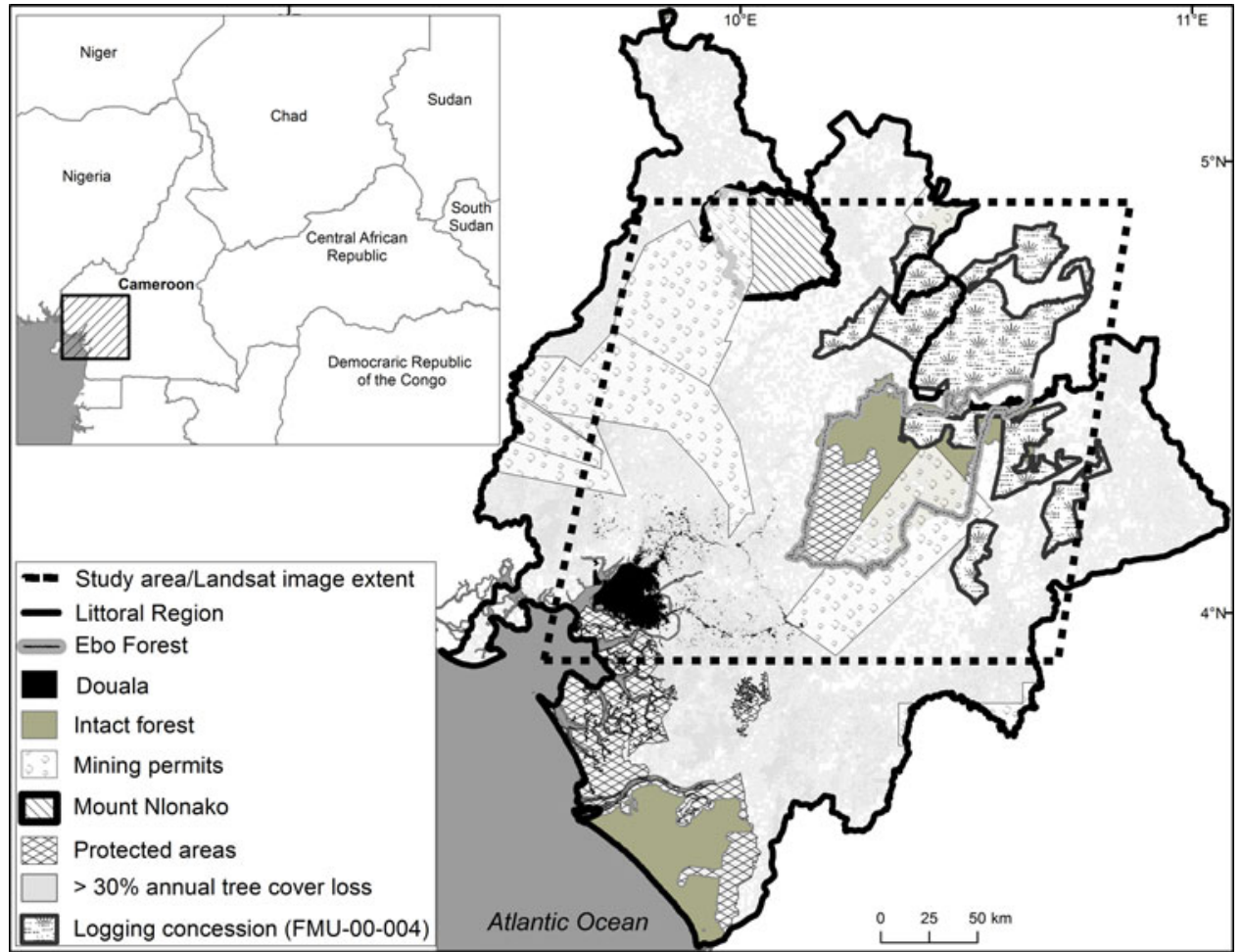

FIG. 1 Locations of Mount Nlonako, Ebo Forest and various human activities within the study area in the Littoral Region of Cameroon. Data for intact forest were derived from the Intact Forest Landscapes (2000-2014) datasets, and data for tree cover loss from the Hansen/ UND/Google/USGS and NASA global dataset. the Planet Labs Inc. application interface (Planet Team, 2017) in conjunction with human land-use interpretations (roads, logging, land clearing and oil palm plantations). These data were then used to assess land-use/land-cover change of natural forest in the study region. Cloud-cover and shadow effects masked parts of the study area, preventing land-cover monitoring of the entire Littoral Region through optical remote sensing.

\section{Categorization and accuracy assessment}

We categorized a cloud-free subset of Landsat images from 1975 and 2017 (covering 13,845 $\mathrm{km}^{2}$ ) that served as the effective study area for this research (Fig. 1). We recognized six major land-cover categories: water body, urban area, cleared land, disturbed vegetation, natural forest and cloud cover. Our land-cover categorization was conducted using the random forest algorithm, which is a machine-learning supervised image classifier (Breiman, 2001). Random homogeneous training and testing samples were collected manually from the 1975 and 2017 images for categorization.

We optimized the accuracy and area of the 1975 and 2017 land-cover maps using the error-adjusted approach (Olofsson et al., 2014). The three steps involved in the approach to determine the map accuracies were sampling, response design and accuracy analysis. As a result, the producer's accuracy, user's accuracy, overall accuracy and confidence intervals were generated for the final landcover maps produced.

\section{Spatio-temporal analysis and mapping fine-scale} drivers of deforestation

We used a three-stage analysis to identify retrospectively the human disturbances (deforestation, land clearing and oil palm plantation development) that threatened forest cover and biodiversity in the study area of the Littoral Region. Firstly, based on the land-cover maps for 1975 and 2017 we investigated hindcast land-cover change to derive and quantify land-cover type change. The change detection approach was used to compute uniform temporal conversion from land cover in an initial state to a subsequent land use, and depict irregular variation verified to be human disturbance and alteration of natural forest.

Secondly, landscape patterns were quantified using the largest patch index computed from the land-cover maps of 1975 and 2017. The index provides quantitative information at the patch, class and landscape levels (Pardini, 2004). We focused on the largest patch index as a useful indicator of fragmentation or aggregation of the land-cover category of interest (in this case natural forest cover). The index is expressed as a percentage of land-cover patch. As the value of the largest patch approaches o, the size of the corresponding patch type decreases. The largest patch index is equal to $100 \%$ when the entire landscape is made up of a single patch that corresponds to the patch type (McGarigal \& Marks, 1995). Hypothetically, a decline in the index from a maximal score of $100 \%$ (equivalent to 1 ) for an intact landscape implies that larger fragments are being re-fragmented, reaching o when all fragments are ultimately converted to a 
different land-cover type. At the category level, the largest patch index (LPI) is computed as:

$$
L P I=\frac{\max _{j=1}^{n}\left(a_{i j}\right)}{A}
$$

where $a_{i j}$ is the area of patch $i j$, subscript $i$ indicates the score for an individual patch within a particular group $j, A$ is the area of the landscape and $n$ is time.

Thirdly, we manually digitized line and polygon features that corresponded to major roads, access roads, logging roads, logging tracks, cleared land and oil palm plantations between 2009 and 2017, using the historical view of the Google Earth image interface (Supplementary Fig. 1). Land-cover maps and relevant land-use layers were integrated. This approach is similar to the concept of data fusion, used to combine multi-source data (Pohl \& Van Genderen, 1998).

\section{Results}

Land-use and land-cover mapping and accuracy analysis

We identified significant land-cover changes between 1975 and 2017 in the Littoral Region (Fig. 2). The confidence of our error-adjusted estimate fell within 95\%, although it was slightly different from that of the mapped areas using the crude land-cover classification maps of 1975 and 2017 (Table 1, Supplementary Table 1). The accuracy of our landcover maps based on the error-adjusted matrix was $90 \%$ for the 1975 data and $96 \%$ for the 2017 data, the producer's accuracy was $89-100 \%$ and the user's accuracy was $71-100 \%$ (Supplementary Table 2).

\section{Spatio-temporal change in fragmentation and landscape}

There was a significant (57\%) increase in the fragmentation of natural forest in the study area (Supplementary Fig. 2a). The largest patch index value for natural forest decreased in mean forest patch size, from $>74 \%$ in 1975 to c. $62 \%$ in 2017 . The values for disturbed vegetation increased from $7.2 \%$ in 1975 to $39.3 \%$ in 2017. Similarly, the largest patch index value for cleared land increased from $0.5 \%$ in 1975 to $5.6 \%$ in 2017 , and for urban area from $1.28 \%$ in 1975 to $7.85 \%$ in 2017 (Supplementary Fig. 2b). We found considerable net change in the gains or losses of the individual land-use/land-cover change types (Fig. 3) between 1975 and 2017, as determined by our spatio-temporal change detection analysis. There was a significant loss of c. 420,00o ha of high-value natural forest cover in the study area from 1975 to 2017 , and an increase of c. 400,00o ha of disturbed vegetation (Fig. 3). Similarly, urban areas, cleared land, and water all increased in area, by $78,631,26,809$ and 3,880 ha, respectively (Fig. 3 ).
Drivers of anthropogenic environmental change at the landscape level

We identified four major factors driving land-cover change in the Littoral Region: the expansion of paved and unpaved major and access roads and rail infrastructure, which facilitated access to remote forest areas; logging; land clearing; and agricultural expansion, especially for palm oil production (Fig. 4). According to our interpretation and digitization of fine-scale land-use maps, the area of oil palm plantation in the study area is $>26,892$ ha and the area of cleared land is at least 34,838 ha (Fig. 4, Supplementary Fig. 3a). The identified unpaved access roads were $>3,012 \mathrm{~km}$ in length, logging roads and deforestation tracks spanned $>443 \mathrm{~km}$, and the total length of paved major roads was c. $205 \mathrm{~km}$ (Supplementary Fig. 3b). Panels A and B of Fig. 4 are enlarged in Supplementary Fig. 4, showing recently logged area, logging roads, cleared land, and oil palm plantations.

\section{Discussion}

\section{Drivers of land-cover change}

The unregulated expansion of human land use and landcover change in the Littoral Region of Central Africa poses irreversible threats to biodiversity and natural forest ecosystems. Our results show that land-cover change since 1975 has substantially modified the forest landscapes of the Littoral Region, including one of the remaining intact forest landscapes, north of Sanga River (Figs 2, 4 \& Supplementary Fig. 4). We found significant and expanding land-cover change within $10 \mathrm{~km}$ of the periphery of Ebo Forest and Mount Nlonako, two important conservation areas in the region (Fig. 4). Our findings are supported by earlier studies (Fa et al., 2006; Potapov et al., 2017), which used coarser datasets but also reported significant tree cover loss, deforestation and biodiversity degradation in the region. Using the fine-scale data in this study, deforestation was found to be driven by multiple human land uses, namely oil palm plantation, logging and land clearing, all of which were facilitated by expansion of the road network that enabled access to the forest. These findings are similar to elsewhere in the tropics where anthropogenic deforestation has been identified as an initial driver of forest degradation leading to progressive land-use changes and ultimately widespread land-cover conversion (Marsik et al., 2011; Renó et al., 2011).

The expansion of oil palm plantations appears to be the major factor driving deforestation in the studied landscapes of the southern Littoral Region. There is evidence that, in general, logging preceded deforestation and is a major facilitator of deforestation (Fig. 4, Supplementary Fig. 5) and the initial step in forest degradation. Logging clears the way for the land to be used for oil palm plantations or cleared 
(a) 1975

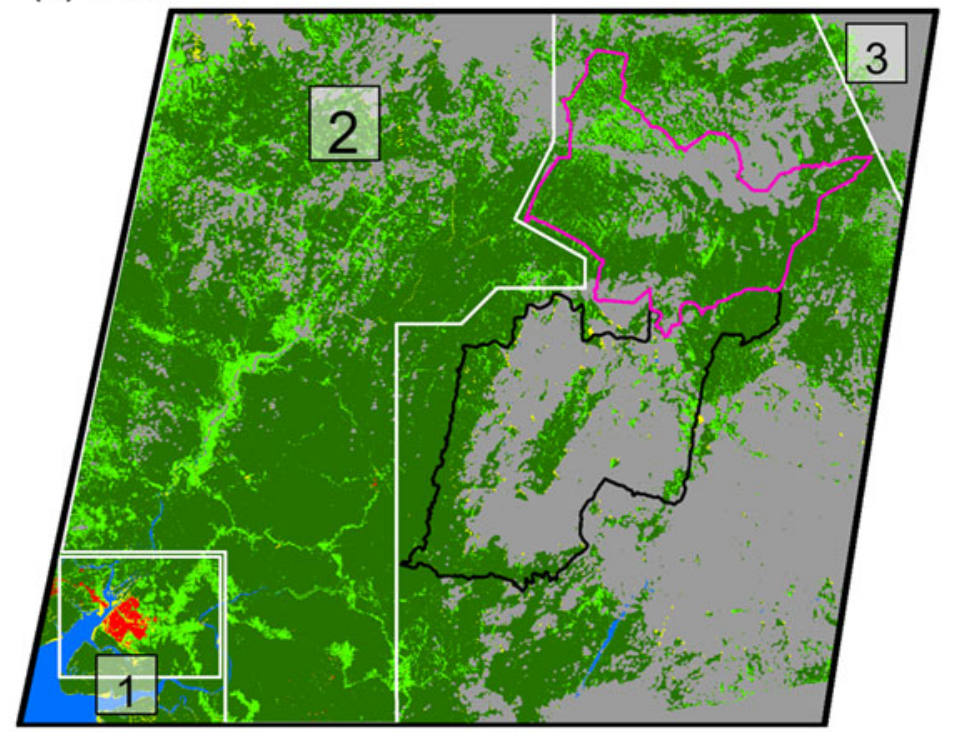

(b) 2017

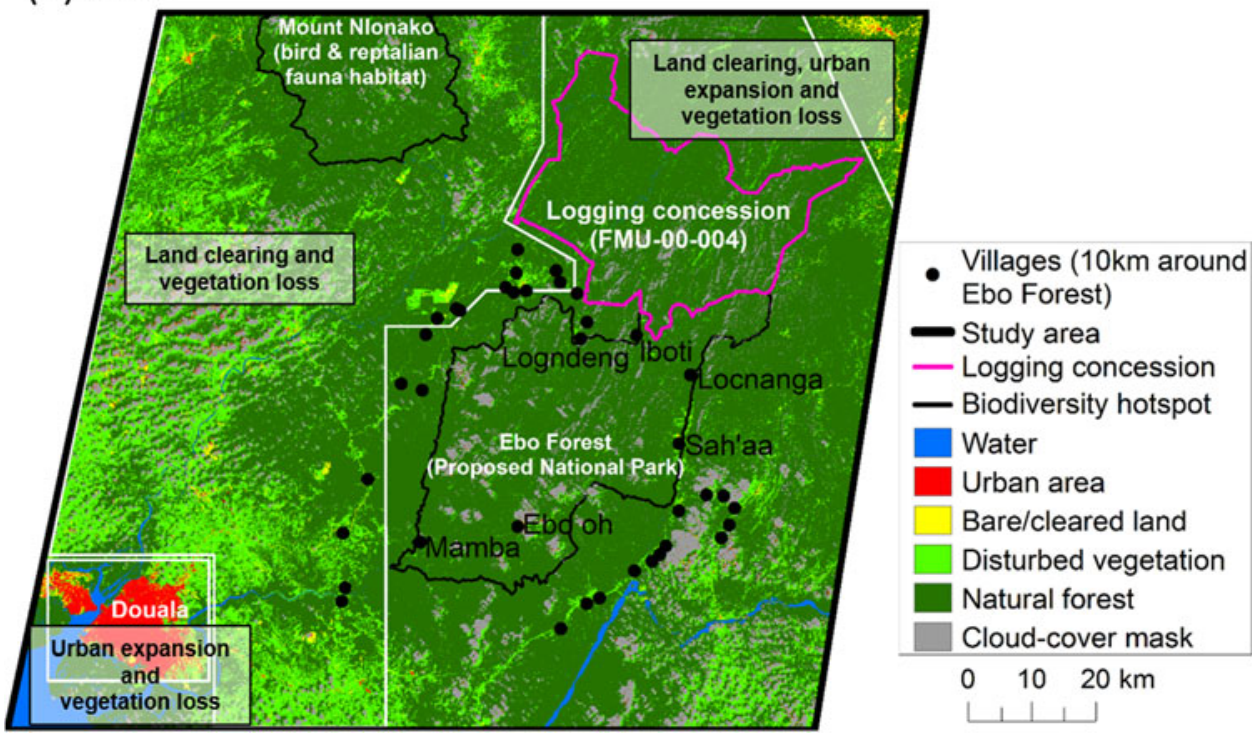

FIG. 2 Land-cover maps of the Littoral Region of Cameroon from (a) 1975 and (b) 2017. Numbers in (a) depict areas with apparent land-cover changes, labelled in (b). for other human use (usually agricultural; Fig. 4, Supplementary Fig. 5). Land clearing in most instances also preceded oil palm plantations (Fig. 4), with plantations again being the final land-cover type in the sequence of land-use conversion (Fig. 4, Supplementary Figs. 5 \& 6). In 2017 oil palm plantations comprised at least half the area of disturbed forests in all parts of the Littoral Region. The dynamics of oil palm expansion and loss of tropical forest in this region appear to be distinct from those in other tropical regions, such as Indonesia (Pirker et al., 2016; Austin et al., 2017) and Colombia (Garcia-Ulloa et al., 2012), where oil palm expansion often occurs at an industrial scale.

In the Littoral Region the majority of oil palm cultivation (c. 60\%) occurs within smallholder agricultural complexes. These smallholder complexes are visually identifiable by mosaics of small, irregularly shaped oil palm stands, typically of $<0.6$ ha, interspersed within subsistence plots, degraded forests and fallows; $55 \%$ are within $5 \mathrm{~km}$ of roads. However, because of limitations of the time-series data for the satellite imagery, it is impossible to confirm whether oil palm expansion was the direct cause of the increase in disturbed vegetation since 1976 or simply the latest land use at these locations. Nevertheless, the fact that smallholder oil palm complexes occur predominantly within remnants of native vegetation suggests that oil palm may be a direct driver of natural forest conversion. Our finding is supported by previous studies in the region, which identified oil palm plantations as one of the major drivers of deforestation (Tamungang et al., 2014; Mitchell et al., 2017). The conversion of natural forests to landscapes dominated by oil palm may also lead to a cascade of ongoing negative conservation outcomes in the region, as evidenced 
TABLE 1 Proportions of various land-cover types in the effective study area $\left(8,915.4 \mathrm{~km}^{2}\right.$ cloud-free of the $13,845 \mathrm{~km}^{2}$ total study area) in the Littoral Region of Cameroon in 1975 and 2017.

\begin{tabular}{|c|c|c|c|c|c|c|}
\hline \multirow[b]{2}{*}{$\begin{array}{l}\text { Land use/land } \\
\text { cover }\end{array}$} & \multicolumn{3}{|l|}{1975} & \multicolumn{3}{|l|}{2017} \\
\hline & $\begin{array}{l}\text { Mapped area } \\
(\%)\end{array}$ & $\begin{array}{l}\text { Estimated area } \\
(\%)\end{array}$ & $\begin{array}{l}\text { Confidence interval } \\
(\%)\end{array}$ & $\begin{array}{l}\text { Mapped area } \\
(\%)\end{array}$ & $\begin{array}{l}\text { Estimated area } \\
(\%)\end{array}$ & $\begin{array}{l}\text { Confidence interval } \\
(\%)\end{array}$ \\
\hline Water & 3.0 & 0.5 & $-0.1-1.6$ & 2.7 & 3.0 & $-0.1-1.6$ \\
\hline Urban area & 0.1 & 0.2 & $-0.1-0.01$ & 5.0 & 5.0 & $-0.1-0.1$ \\
\hline Cleared land & 0.2 & 0.5 & $-0.2-0.2$ & 2.2 & 3.0 & $-0.2-0.2$ \\
\hline $\begin{array}{l}\text { Disturbed } \\
\text { vegetation }\end{array}$ & 31.0 & 16.0 & $-2.0-2.0$ & 37.0 & 38.0 & $-0.1-0.1$ \\
\hline Natural forest & 63.0 & 72.0 & $-0.1-0.3$ & 53.1 & 51.0 & $-0.1-0.1$ \\
\hline
\end{tabular}

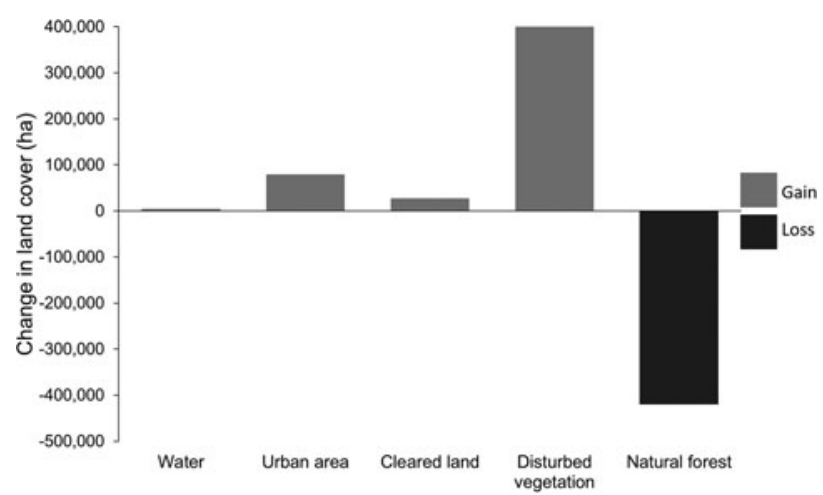

FIG. 3 Change in land cover (water, urban area, cleared land, disturbed vegetation, natural forest) in the $8,916 \mathrm{~km}^{2}$ study area in the Littoral Region of Cameroon (Fig. 1) between 1975 and 2017.

in South-east Asian landscapes where oil palm plantations have had negative effects on the abundance and occurrence of a wide range of taxa, including birds, invertebrates and mammals (Fitzherbert et al., 2008; Yue et al., 2015). Oil palm expansion in the south of the Littoral Region landscape is a major driver of current and ongoing regional deforestation, although Ebo Forest is protected to some degree by its steep and hilly terrain, which makes it less accessible.

Logging and land clearing are two other major drivers of deforestation we observed in the north-west of the Littoral Region. The proximity of a government-sanctioned active 30-year logging concession (FMU-Oo-004), adjacent to Ebo Forest in the north-east of the Littoral Region (Fig. 4), is a potential threat to the biodiversity of Ebo Forest and is a concern for unprotected forests in the region, which are also threatened by the extensive areas of sanctioned logging and mining concessions (Fig. 1).

The infiltration of roads into the studied forests appears to have contributed substantially to the progressive deforestation in the region; for example, roads were found in all human-modified land uses, including deforested areas. Additionally, most of the identified deforestation occurred within $5 \mathrm{~km}$ of a forest edge, near roads. These observations combined suggest that forest degradation and deforestation are facilitated by the increased access to intact forests that the roads provide (Fig. 4). Moreover, roads have facilitated the expansion of human habitations, which are now present within $10 \mathrm{~km}$ of Ebo Forest (Figs. 2b, 4, \& Supplementary Fig. 7); a process increasingly threatening biodiversity and wildlife habitats and their conservation (Brandão, Jr \& Souza, Jr, 2006; Pfaff et al., 2007).

\section{Forest fragmentation}

There was a significant increase in forest fragmentation between 1975 and 2017 in the Littoral Region. For instance, there was a pronounced decline in inter-patch habitat connectivity in the forested area, as indicated by the significant decline in the extent of natural forest (Fig. 3). Connectivity is considered to be essential for conserving biodiversity at the landscape scale (Hodgson et al., 2011) and facilitating the movement of fauna (Vogt et al., 2009), and therefore the isolation of many forest patches in the study area threatens biodiversity (Fahrig, 2013) and the genetic integrity of the remnant species (Young et al., 1996). If the current trend in logging and farming activities is sustained there is likely to be ongoing isolation of natural forest in patches, which may lead to further biodiversity loss. This is because larger patches of natural forest provide better protection for a variety of habitats, and withstand anthropogenic threats and degradation better than smaller, fragmented forests (Laurance et al., 2018). The current trajectory of human land use in the region suggests that significant conservation areas, such as Ebo Forest, are increasingly at risk from fragmentation and isolation of forest patches. A comparison of the 1975 and 2017 land-cover maps, for instance, revealed that substantial fragmentation occurred in the forest landscapes of the Littoral Region as a result of deforestation (Fig. 3). The observed fragmentation and deforestation began in degraded areas and expanded gradually into natural forest, resulting in an increase in the area of disturbed vegetation (Fig. 2). 


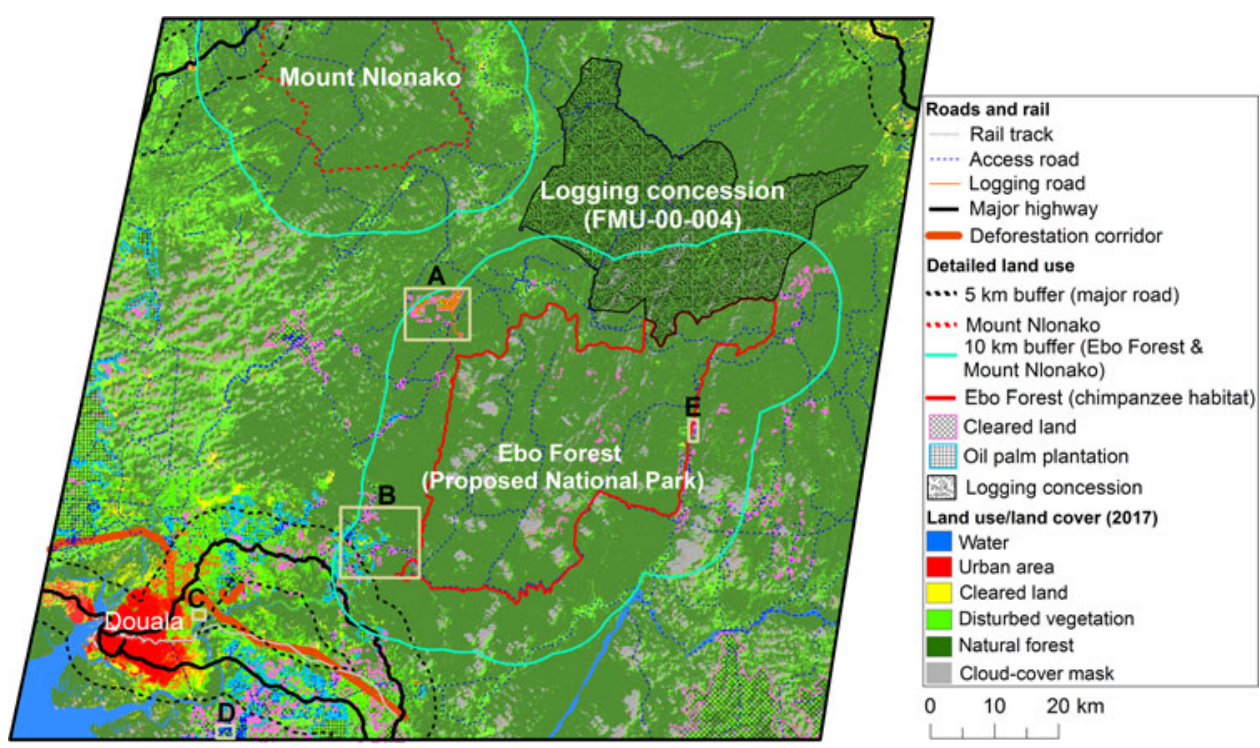

FIG. 4 Spatially explicit drivers of deforestation overlain on a 2017 land-cover map (as base layer) in the $13,845 \mathrm{~km}^{2}$ study area encompassing Ebo Forest and Mount Nlonako, Cameroon (Fig. 1). For detailed views of panels $\mathrm{A}-\mathrm{E}$, see Supplementary Figs 4-7.

\section{Implications for conservation}

Deforestation of natural forests and the conversion of forested land for smallholder agricultural practices in the Littoral Region of Cameroon have numerous negative implications for regional biodiversity and wildlife conservation, ecosystem functioning, environmental sustainability and livelihoods. Regarding biodiversity and wildlife, multiple anthropogenic influences are threatening forests, with many direct impacts, depending upon the extent and type of forest altered. For instance, the observed deforestation and the replacement of natural forest with oil palm plantations is likely to result in severe biodiversity loss (Fitzherbert et al., 2008; Azhar et al., 2014). In South-east Asia forest conversion to oil palm cultivation has had severe negative effects on biodiversity across a wide range of taxa, including birds, invertebrates and mammals (Peh et al., 2006; Koh \& Wilcove, 2008; Vargas et al., 2015; Yue et al., 2015). Hence, our findings forewarn of potential loss of biodiversity and wildlife habitat in the Littoral Region as a result of deforestation for oil palm cultivation.

With the current trajectory of land-cover change, we infer that functioning of forested ecosystems in the Littoral Region is under threat as a result of the landscape-level loss of forest cover, which can alter biogeochemical cycles and induce climate change. Moreover, degradation of ecosystem functioning in the forests of the Littoral Region is expected to continue as anthropogenic land use gradually encroaches on areas once occupied by natural forest (Gérard et al., 2017; Nicholas et al., 2018). There are likely to be other cascading implications of forest land-cover change, including soil degradation, in the Littoral Region. Removal of natural forest cover exposes soils, which results in potentially irreversible soil erosion, degradation and threats to soil biota (Danielsen et al., 2009; Beca et al.,
2017). Deforestation processes therefore pose substantial risks to the integrity and long-term sustainability of forests through numerous mechanisms.

Outright conversion and loss of natural tropical forest increases net greenhouse gas emissions (Houghton \& Nassikas, 2017), contributing to human-induced climate change. The ongoing conversion of the forests in the Littoral Region, which is occurring at a landscape level, will therefore contribute to greenhouse gas emissions in Cameroon and global human-induced climate change.

Long-term human well-being in the Littoral Region is also threatened by the loss of natural forest cover. The forests in the Littoral Region harbour numerous medicinally useful species, which are used by local people and are in demand from global pharmaceutical companies (Colfer, 2012; Watson et al., 2018). The potential extinction of these medicinal plants as a result of deforestation in the Littoral Region has significant implications for the local populace, and legislative protection of the forests is needed to avoid this scenario. Otherwise, if the expansion of oil palm cultivation, mining, logging, land clearing and hunting towards the boundary of Ebo Forest is not halted, the combined effects will deny people medicinal support, decrease the quality of life in the region, and have significant socio-economic impacts.

\section{Conclusions}

Land-cover conversion is an insidious and increasing threat to the forests and biodiversity in the Littoral Region of Cameroon. Significant deforestation has occurred in the study region, reducing natural forest cover from $74.2 \%$ in 1975 to $62.3 \%$ in 2017 . This forest loss occurred predominantly within $5 \mathrm{~km}$ of major roads, and is now occurring 
within $10 \mathrm{~km}$ of important biodiversity and wildlife habitats. It is clear that the cumulative effects of human actions such as the establishment and expansion of oil palm plantations, logging, land clearing, and expansion of roads and settlements are driving deforestation in the periphery of important forested areas, particularly those of Ebo Forest and Mount Nlonako. There are numerous negative implications of the observed environmental change in the study area, including habitat and biodiversity loss, a decline in ecosystem services, and a decrease in the availability of medicinal forest products. In particular, the current rate of land conversion, and its proximity, suggests that Ebo Forest is highly threatened, given its current lack of legislative protection. It is not an overstatement to say that the continued pace of human actions and environmental change in the areas surrounding Ebo Forest forewarn of serious ecological and conservation threats to the forest if legislative action is not taken swiftly, including the implementation of a proactive environmental management plan for the biologically diverse unprotected forests in the Littoral Region and Cross-Sanga River landscapes.

Acknowledgements Financial support for this study was provided by the Arcus Foundation and James Cook University. We thank Pontus Olofsson for verification of the error-adjusted area estimates, and the Editor and reviewers for their comments and suggestions.

Author contributions Study conceptualization, data analysis and writing: MIM; revision: all authors.

\section{Conflicts of interest None.}

Ethical standards This research complied with the Oryx guidelines on ethical standards.

\section{References}

Abernethy, K., Maisels, F. \& White, L.J.T. (2016) Environmental issues in Central Africa. Annual Review of Environment and Resources, 41, 1-33.

Alamgir, M., Campbell, M.J., Sloan, S., Goosem, M., Clements, G.R., Mahmoud, M.I. \& Laurance, W.F. (2017) Economic, socio-political and environmental risks of road development in the tropics. Current Biology, 27, R1130-R1140.

Aleman, J.C., Jarzyna, M.A. \& Staver, A.C. (2018) Forest extent and deforestation in tropical Africa since 1900. Nature Ecology \& Evolution, 2, 26-33.

Austin, K.G., Mosnier, A., Pirker, J., McCallum, I., Fritz, S. \& Kasibhatla, P.S. (2017) Shifting patterns of oil palm driven deforestation in Indonesia and implications for zero-deforestation commitments. Land Use Policy, 69, 41-48.

Azhar, B., Lindenmayer, D.B., Wood, J., Fischer, J. \& Zakaria, M. (2014) Ecological impacts of oil palm agriculture on forest mammals in plantation estates and smallholdings. Biodiversity and Conservation, 23, 1175-1191.

Beca, G., Vancine, M.H., Carvalho, C.S., Pedrosa, F., Alves, R.S.C., BusCARIOL, D. et al. (2017) High mammal species turnover in forest patches immersed in biofuel plantations. Biological Conservation, 210, 352-359.
Brandão, JR, A.O. \& Souza, JR, C.M. (2006) Mapping unofficial roads with Landsat images: a new tool to improve the monitoring of the Brazilian Amazon rainforest. International Journal of Remote Sensing, 27, 177-189.

Breiman, L. (2001) Random forests. Machine Learning, 45, 5-32.

Cetin, M. (2015) Evaluation of the sustainable tourism potential of a protected area for landscape planning: a case study of the ancient city of Pompeipolis in Kastamonu. International Journal of Sustainable Development and World Ecology, 22, 490-495.

Cheek, M., Cable, S., Hepper, F.N., Ndam, N. \& Watts, J. (1996) Mapping plant biodiversity on Mount Cameroon. In The Biodiversity of African Plants (eds L.J.G. van der Maesen, X.M. van der Burgt \& J.M. van Medenbach de Rooy), pp. 110-120. Kluwer Academic Publishers, Dordrecht, The Netherlands.

Cincotta, R.P., Wisnewski, J. \& Engelman, R. (2000) Human population in the biodiversity hotspots. Nature, 404, 990-992.

Colfer, C.J.P. (2012) Human Health and Forests: a Global Overview of Issues, Practice and Policy. Routledge, London, UK.

Danielsen, F., Beukema, H., Burgess, N.D., Parish, F., Brühl, C.A., Donald, P.F. et al. (2009) Biofuel plantations on forested lands: double jeopardy for biodiversity and climate. Conservation Biology, 23, 348-358.

Fa, J.E., Seymour, S., Dupain, J., Amin, R., Albrechtsen, L. \& MACDONALD, D. (2006) Getting to grips with the magnitude of exploitation: bushmeat in the Cross-Sanaga rivers region, Nigeria and Cameroon. Biological Conservation, 129, 497-510.

FAHRIG, L. (2003) Effects of habitat fragmentation on biodiversity. Annual Review of Ecology, Evolution, and Systematics, 34, 487-515.

FAHRIG, L. (2013) Rethinking patch size and isolation effects: the habitat amount hypothesis. Journal of Biogeography, 40, 1649-1663.

Feintrenie, L. (2012) Oil palm in Cameroon: risks and opportunities. Nature \& Faune, 26, 23-27.

Fitzherbert, E.B., Struebig, M.J., Morel, A., Danielsen, F., BRÜhl, C.A., Donald, P.F. \& Phalan, B. (2008) How will oil palm expansion affect biodiversity? Trends in Ecology \& Evolution, 23, 538-545.

Garcia-Ulloa, J., Sloan, S., Pacheco, P., Ghazoul, J. \& Koh, L.P. (2012) Lowering environmental costs of oil-palm expansion in Colombia. Conservation Letters, 5, 366-375.

Gérard, A., Wollni, M., Hölscher, D., Irawan, B., Sundawati, L., Teuscher, M. \& Kreft, H. (2017) Oil-palm yields in diversified plantations: initial results from a biodiversity enrichment experiment in Sumatra, Indonesia. Agriculture, Ecosystems \& Environment, 240, 253-260.

Haddad, N.M., Brudvig, L.A., Clobert, J., Davies, K.F., Gonzalez, A., Holt, R.D. et al. (2015) Habitat fragmentation and its lasting impact on Earth's ecosystems. Science Advances, 1, e1500052.

Hodgson, J.A., Moilanen, A., Wintle, B.A. \& Thomas, C.D. (2011) Habitat area, quality and connectivity: striking the balance for efficient conservation. Journal of Applied Ecology, 48, 148-152.

Hosonuma, N., Herold, M., De Sy, V., De Fries, R.S., Brockhaus, M., Verchot, L. et al. (2012) An assessment of deforestation and forest degradation drivers in developing countries. Environmental Research Letters, 7, 044009.

Houghton, R.A. \& Nassikas, A.A. (2017) Global and regional fluxes of carbon from land use and land cover change 1850-2015. Global Biogeochemical Cycles, 31, 456-472.

Ingram, V., Ewane, M., Ndumbe, L.N. \& Awono, A. (2017) Challenges to governing sustainable forest food: Irvingia spp. from southern Cameroon. Forest Policy and Economics, 84, 29-37.

KoH, L.P. \& Wilcove, D.S. (2008) Is oil palm agriculture really destroying tropical biodiversity? Conservation Letters, 1 , $60-64$. 
Laporte, N.T., Stabach, J.A., Grosch, R., Lin, T.S. \& Goetz, S.J. (2007) Expansion of industrial logging in Central Africa. Science, $316,1451$.

Laurance, W.F., Sloan, S., Weng, L. \& Sayer, J.A. (2015) Estimating the environmental costs of Africa's massive 'development corridors'. Current Biology, 25, 3202-3208.

Laurance, W.F., Campbell, M.J., Alamgir, M. \& Mahmoud, M.I. (2017) Road expansion and the fate of Africa's tropical forests. Frontiers in Ecology and Evolution, 5, 1-7.

Laurance, W.F., Camargo, J.L.C., Fearnside, P.M., Lovejoy, T.E., Williamson, G.B., Mesquita, R.C.G. et al. (2018) An Amazonian rainforest and its fragments as a laboratory of global change. Biological Reviews, 93, 223-247.

Mahmoud, M.I., Duker, A., Conrad, C., Thiel, M. \& Ahmad, H.S. (2016) Analysis of settlement expansion and urban growth modelling using geoinformation for assessing potential impacts of urbanization on climate in Abuja city, Nigeria. Remote Sensing, $8,220$.

Mahmoud, M.I., Sloan, S., Campbell, M.J., Alamgir, M., Imong, I., Odigha, O. et al. (2017) Alternative routes for a proposed Nigerian superhighway to limit damage to rare ecosystems and wildlife. Tropical Conservation Science, 10, 1-10.

Marsik, M., Stevens, F.R. \& Southworth, J. (2011) Amazon deforestation: rates and patterns of land cover change and fragmentation in Pando, northern Bolivia, 1986 to 2005. Progress in Physical Geography: Earth and Environment, 35, 353-374.

McGarigal, K. \& Marks, B.J. (1995) Fragstats: Spatial Pattern Analysis Program for Quantifying Landscape Structure. USDA Forest Service General Technical Report PNW-GTR-351.

Mitchell, A.L., Rosenqvist, A. \& Mora, B. (2017) Current remote sensing approaches to monitoring forest degradation in support of countries measurement, reporting and verification (MRV) systems for REDD+. Carbon Balance and Management, 12, 9.

Molua, E.L. (2009) Accommodation of climate change in coastal areas of Cameroon: selection of household-level protection options. Mitigation and Adaptation Strategies for Global Change, $14,721$.

Morgan, B.J., Adeleke, A., Bassey, T., Bergl, R.A., Dunn, A., Fotso, R. et al. (2011) Regional Action Plan for the Conservation of the Nigeria-Cameroon Chimpanzee (Pan troglodytes ellioti). IUCN/ SSC Primate Specialist Group and Zoological Society of San Diego, California, USA.

Nicholas, K.M., Fanzo, J. \& MacManus, K. (2018) Palm oil in Myanmar: a spatiotemporal study of how industrial farming affects biodiversity loss and the sustainable diet. Global Health: Science and Practice, 6, 210-222.

Oates, J.F., Bergl, R.A. \& Linder, J.M. (2004) Africa's Gulf of Guinea Forests: Biodiversity Patterns and Conservation Priorities. Center for Applied Biodiversity Science, Conservation International, Washington, DC, USA.

Olofsson, P., Foody, G.M., Herold, M., Stehman, S.V., Woodcock, C.E. \& W Ulder, M.A. (2014) Good practices for estimating area and assessing accuracy of land change. Remote Sensing of Environment, 148, 42-57.

Ordway, E.M., Asner, G.P. \& Lambin, E.F. (2017) Deforestation risk due to commodity crop expansion in sub-saharan Africa. Environmental Research Letters, 12, 044015.

Orme, C.D.L., Davies, R.G., Burgess, M., Eigenbrod, F., Pickup, N., Olson, V.A. et al. (2005) Global hotspots of species richness are not congruent with endemism or threat. Nature, 436, 1016-1019.

PARDINI, R. (2004) Effects of forest fragmentation on small mammals in an Atlantic Forest landscape. Biodiversity and Conservation, 13, $2567-2586$.
Peh, K.S.H., Sodhi, N.S., De Jong, J., Sekercioglu, C.H., Yap, C.A.M. \& LIM, S.L.H. (2006) Conservation value of degraded habitats for forest birds in southern Peninsular Malaysia. Diversity and Distributions, 12, 572-581.

Pfaff, A., Robalino, J., Walker, R., Aldrich, S., Caldas, M., Reis, E. et al. (2007) Road investments, spatial spillovers, and deforestation in the Brazilian Amazon. Journal of Regional Science, $47,109-123$.

Pirker, J., Mosnier, A., Krayner, F., Havlík, P. \& Obersteiner, M. (2016) What are the limits to oil palm expansion? Global Environmental Change, 40, 73-81.

Planet Team (2017) Planet Application Program Interface: in Space for Life on Earth. Planet Team, San Francisco, USA. Https://api. planet.com [accessed 19 December 2017].

Pohl, C. \& Van Genderen, J.L. (1998) Multisensor image fusion in remote sensing: concepts, methods and applications. International Journal of Remote Sensing, 19, 823-854.

Potapov, P., Hansen, M.C., Laestadius, L., Turubanova, S., Yaroshenko, A., Thies, C. et al. (2017) The last frontiers of wilderness: tracking loss of intact forest landscapes from 2000 to 2013. Science Advances, 3, e1600821.

Renó, V.F., Novo, E.M.L.M., Suemitsu, C., Rennó, C.D. \& Silva, T.S.F. (2011) Assessment of deforestation in the Lower Amazon floodplain using historical Landsat MSS/TM imagery. Remote Sensing of Environment, 115, 3446-3456.

Singh, S.K., Srivastava, P.K., Szabó, S., Petropoulos, G.P., Gupta, M. \& Islam, T. (2017) Landscape transform and spatial metrics for mapping spatiotemporal land cover dynamics using Earth Observation data-sets. Geocarto International, 32, 113-127.

Sosef, M.S.M., Dauby, G., Blach-Overgaard, A., van der Burgt, X., Catarino, L., Damen, T. et al. (2017) Exploring the floristic diversity of tropical Africa. BMC Biology, 15, 15.

Tamungang, S.A., Cheke, R.A., Mofor, G.Z., Tamungang, R.N. \& OвEN, F.T. (2014) Conservation concern for the deteriorating geographical range of the grey parrot in Cameroon. International Journal of Ecology, 2014, 753294.

Tchuenté, A.T.K., Roujean, J.-L. \& De Jong, S.M. (2011) Comparison and relative quality assessment of the GLC20oo, GLOBCOVER, MODIS and ECOCLIMAP land cover data sets at the African continental scale. International Journal of Applied Earth Observation and Geoinformation, 13, 207-219.

Thompson, P.L., Rayfield, B. \& GonZalez, A. (2017) Loss of habitat and connectivity erodes species diversity, ecosystem functioning, and stability in metacommunity networks. Ecography, 40, 98-108.

van Soesbergen, A., Arnell, A.P., Sassen, M., Stuch, B., SCHALDACH, R., Göpel, J. et al. (2017) Exploring future agricultural development and biodiversity in Uganda, Rwanda and Burundi: a spatially explicit scenario-based assessment. Regional Environmental Change, 17, 1409-1420.

Vargas, L.E.P., Laurance, W.F., Clements, G.R. \& Edwards, W. (2015) The impacts of oil palm agriculture on Colombia's biodiversity: what we know and still need to know. Tropical Conservation Science, 8, 828-845.

Vogt, P., Ferrari, J.R., Lookingbill, T.R., Gardner, R.H., Rittters, K.H. \& Ostapowicz, K. (2009) Mapping functional connectivity. Ecological Indicators, 9, 64-71.

Watson, J.E.M., Evans, T., Venter, O., Williams, B., Tulloch, A., Stewart, C. et al. (2018) The exceptional value of intact forest ecosystems. Nature Ecology \& Evolution, 2, 599-610.

Whytock, R.C., Buij, R., Virani, M.Z. \& Morgan, B.J. (2016) Do large birds experience previously undetected levels of hunting pressure in the forests of Central and West Africa? Oryx, 50, $76-83$. 
Wiens, J., Sutter, R., Anderson, M., Blanchard, J., Barnett, A., Aguilar-Amuchastegui, N. et al. (2009) Selecting and conserving lands for biodiversity: the role of remote sensing. Remote Sensing of Environment, 113, 1370-1381.

Willis, K.S. (2015) Remote sensing change detection for ecological monitoring in United States protected areas. Biological Conservation, 182, 233-242.
WWF (2017) Congo Basin. Https://www.worldwildlife.org/places/ congo-basin [accessed 6 November 2017].

Young, A., Boyle, T. \& Brown, T. (1996) The population genetic consequences of habitat fragmentation for plants. Trends in Ecology \& Evolution, 11, 413-418.

Yue, S., Brodie, J.F., Zipkin, E.F. \& Bernard, H. (2015) Oil palm plantations fail to support mammal diversity. Ecological Applications, 25, 2285-2292. 